\title{
Studi Eksperimen Pengaruh Penambahan Serabut Kelapa Terhadap Kohesi dan Sudut Geser Tanah Lempung
}

\author{
Pebrinar R. Sangle \\ Dosen Program Studi Teknik Sipil, Universitas Kristen Indonesia Paulus, Makassar, Indonesia \\ pebrinar sangle@ukipaulus.ac.id
}

\begin{abstract}
ABSTRAK
Penelitian ini bertujuan untuk mengetahui kuat geser tanah lempung sebelum dan setelah ditambahkan serabut kelapa. Untuk menghitung daya dukung tanah maka salah satu faktor yang perlu kita ketahui adalah kuat geser. Dalam memperbaiki ataupum mengubah suatu sifat tanah dasar yang kurang baik menjadi lebih baik agar dapat menopang konstruksi diatasnya maka perlu dilakukan upaya stabilitas tanah. Pengujian parameter kuat geser menggunakan alat uji geser langsung dengan kondisi tegangan total. Penelitian ini menggunakan variasi serabut kelapa $0 \%, 1 \%, 2 \%, 3 \%$ dan $4 \%$ terhadap berat kering tanah. hasil pengujian geser langsung (direct shear test) menunjukkan adanya peningkatan nilai kohesi (c) dan sudut geser $(\varphi)$ tanah. Hal ini menunjukkan bahwa penambahan serabut kelapa pada tanah lempung dapat meningkatkan nilai kuat geser.
\end{abstract}

Kata Kunci : Tanah Lempung, Serabut Kelapa, Kohesi, Sudut Geser

\section{ABSTRACT}

This research is intended to study the shear strength of clay soil before and after adding coconut fibers. Shear strength is one of the factors that are taken into account to find the bearing capacity of the soil. Soil stability is a way to improve or change the nature of an unfavorable subgrade condition to be better in terms of the bearing capacity of the subgrade for the construction to be built on its Strength parameter testing shear using direct shear test equipment with total stress conditions. This research used coconut fiber variations of $0 \%, 1 \%, 2 \%, 3 \%$, and $4 \%$ of the dry weight of the soil. The results of the direct shear test showed an increase in the value of soil cohesion (c) and shear angle $(\varphi)$. This shows that the addition of coconut fibers to clay soil can increase the value of shear strength.

Keywords: Clay Soil, Coconut Fiber, Cohesion, Angle of Shear

\section{PENDAHULUAN}

Longsoran sering terjadi pada lokasi yang memiliki kondisi geologi, marfologi, hidrologi dan iklim yang kurang menguntungkan. Longsoran secara alami terjadi antara lain karena menurunnya kemantapan suatu lereng akibat degradasi tanah/batuan bersamaan waktu dan usianya ataupun akibat meningkatnya tegangan geser suatu tanah dan menurunnya kuat geser tanah. Hal ini terjadi apabila beban yang harus dipikul oleh massa tanah melebihi kekuatan geser tanah tersebut. Kejadian seperti ini biasanya terjadi akibat ulah manusia ataupun kondisi dari alam. Misalnya dengan intensitas curah hujan yang tinggi sehingga mengakibatkan tanah jenuh air yang menyebabkan kuat geser tanah tidak menentu sehingga tanah menjadi rawan longsor.
Tanah lempung merupakan salah satu tanah yang bersifat lunak dan merupakan tanah yang kohesif. Tanah lempung memiliki daya dukung yang rendah serta sangat mudah menyerap air serta susah melepaskannya. Tanah lempung akan mengalami perubahan volume tergantung besarnya kadar air yang terkandung didalamnya. Hal ini mengakibatkan tanah lempung yang kering akan terjadi retakan dan biala memiliki kadar air tinggi maka akan mengalami swelling (pengembangan). Swelling pada tanah lempung juga sangat bergantung pada konstruksi yang di topang, apabila konstruksi yang ada diatasnya maka tanah akan mengembang dan apabila kontruksinya berat maka tanah akan menyusut.

Serabut kelapa khususnya di Sulawesi Selatan selama ini banyak digunakan untuk industri rumah tangga baik berupa bahan 
Paulus Civil Engineering Journal

Jurnal Teknik Sipil UKI-Paulus Makassar https://doi.org/10.52722/pcej.v3i2.3216
Volume 3 No.2, Juni 2021

e-ISSN 2775-4529

p-ISSN 2775-8613 bakar maupun souvenir, sehingga pada penelitian ini dimemanfaatkan serabut kelapa sebagai salah satu untuk perbaikan tanah dasar. Pemilihan serabut kelapa sebagai bahan stabilisasi/ perbaikan tanah dikarenakan serabut kelapa bahan yang mudah meloloskan air (B. Army dan Liliwarti, 2009) dan juga mudah didapatkan dimana saja.

\section{METODOLOGI PENELITIAN}

\section{Tahapan penelitian}

Tahapan penelitian yang dilakukan di laboratorium dapat dilihat pada Gambar 1 berikut:

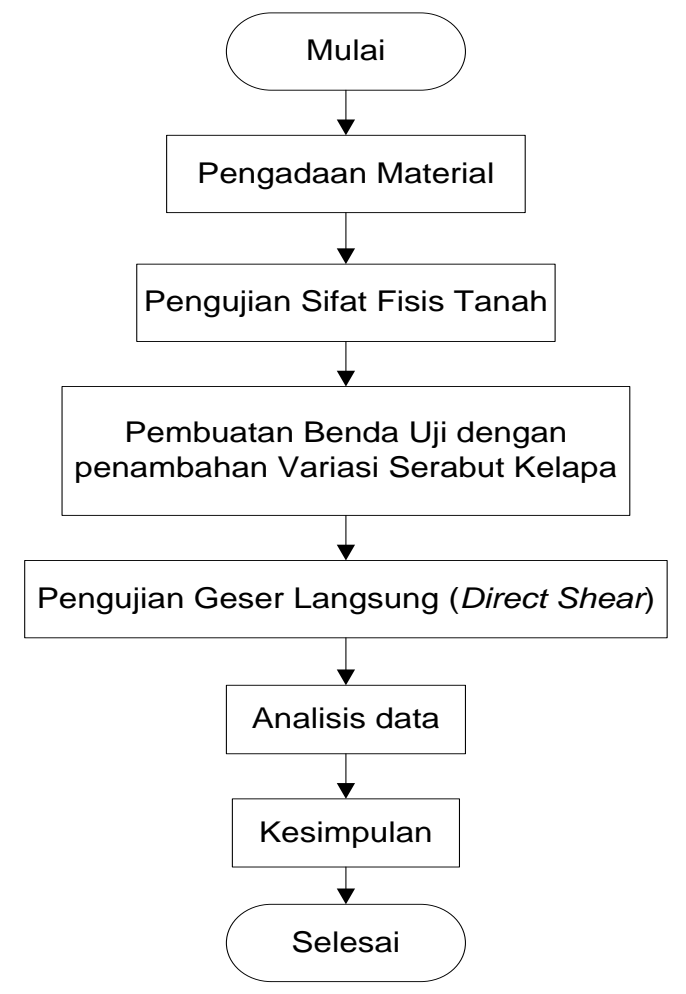

Gambar 1. Bagan Alir Penelitian

2. Pengadaan Material dan Pengujian Sifat Fisis Tanah
Pengujian sifat bahan ini bertujuan untuk mengetahui karakteristik bahan yang akan digunakan dalam penelitian. Apakah bahan tersebut sudah sesuai dengan spesifikasi yang telah ditentukan.

\section{Bahan Tambahan Serabut Kelapa}

Serabut kelapa merupakan bahan berserat dengan ketebalan sekitar $5 \mathrm{~cm}$ dan merupakan bagian teluar dari buah kelapa. Sabut kelapa terdiri dari kulit ari, serat dan sekam (dust). Menurut United Coconut Association of the Philipines (UCAP), dari 1 buah kelapa dapat di peroleh rata- rata $0,4 \mathrm{~kg}$ serabut kelapa. Serabut tersebut mengandung $30 \%$ serat serta serabut kelapa banyak mengandung unsur kalium.

\section{Pengujian Sifat fisik tanah}

- Uji Kadar Air (ASTM D 2216)

- Uji Berat Jenis Tanah (ASTM 854)

- Uji Batas-batas Atterberg (ASTM 4318-95)

- Uji Analisa Butiran (ASTM D 42263) dan ( ASTM D 1140-54)

Pengujian Geser Langsung (Direct Shear Test)

Pengujian geser langsung bertujuan untuk menentukan besarnya parameter kuat tekan geser tanah yang terdiri dari sudut geser $(\varphi)$ dan kohesi (c) dengan alat uji geser langsung pada kondisi consolidated drained. Pengujian geser langsung berdasarkan AASHTO T208-72 dan ASTM 2166-68

\section{ANALISIS DAN PEMBAHASAN}

Data dan Analisis Kuat Geser Tanah

\section{Pengujian Sifat Fisis Tanah}

Hasil pengujian sifat fisis tanah dapat dilihat pada tabel 1

Tabel 1. Hasil pengujian Sifat Fisis Tanah

\begin{tabular}{cllrlc}
\hline No & Pemeriksaan & & & & Nilai \\
\hline 1 & Kadar Air & & $($ w) & $\%$ & 29.68 \\
2 & Berat Jenis & Batas Cair & (Gs) & & 2.59 \\
& & Batas Plastis & (Liquid Limit) & & 38.48 \\
& & (Plastic Limit) & $\%$ & 21.22 \\
3 & Batas-Batas Atterberg & Batas Susut & (Shirnkage Limit) & $\%$ & 6.32 \\
& & Indeks Plastisitas & (Plasticity Index) & $\%$ & 17.25 \\
& & Gradasi Butiran & Persen lolos saringan no. 200 & $\%$ & 83.27 \\
\hline
\end{tabular}




\begin{tabular}{llcc}
\hline Gravel & $\mathrm{G}$ & $\%$ & 0.00 \\
Sand & $\mathrm{S} \%$ & 16.73 \\
Silt & $\mathrm{M} \%$ & 78.20 \\
Clay & $\mathrm{C} \%$ & 5.07 \\
\hline
\end{tabular}

Berdsarkan hasil pengujian fisik dan mekanis dari sampel tanah maka, tanah yang digunakan adalah jenis tanah lempung organik dengan plastisitas sedang.

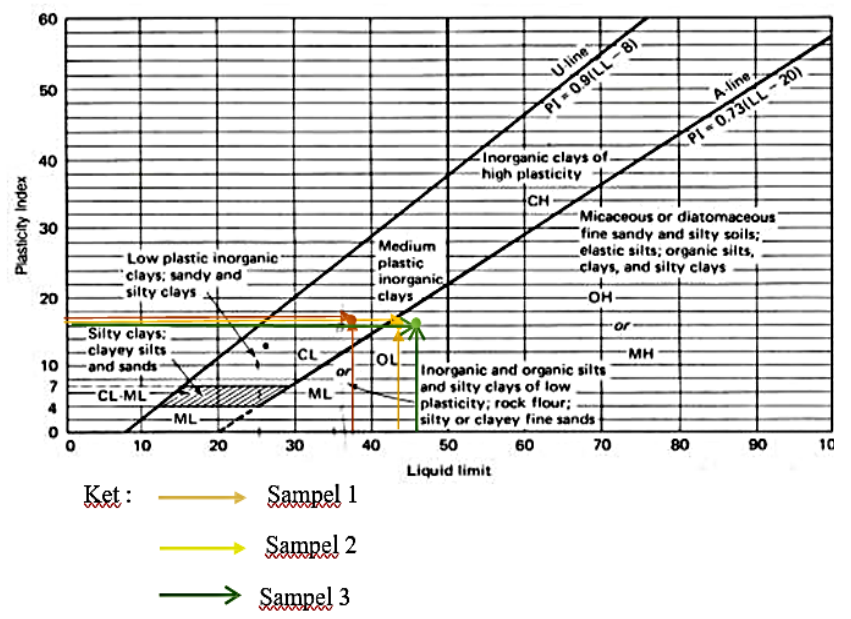

Gambar 2. Grafik Plasticity Chart

\section{Pengujian Geser Langsung (Direct Shear Test)}

Tabel 2. Hasil pengujian geser langsung (kohesi)

\begin{tabular}{cccc}
\hline Variasi serabut & \multicolumn{3}{c}{ Kohesi $\left(\mathrm{Kg} / \mathrm{cm}^{2}\right)$} \\
$(\%)$ & Sampel 1 & Sampel 2 & Sampel 3 \\
\hline 0 & 0.05 & 0.01 & 0.03 \\
1 & 0.06 & 0.02 & 0.04 \\
2 & 0.06 & 0.02 & 0.05 \\
3 & 0.07 & 0.03 & 0.06 \\
4 & 0.07 & 0.03 & 0.07
\end{tabular}

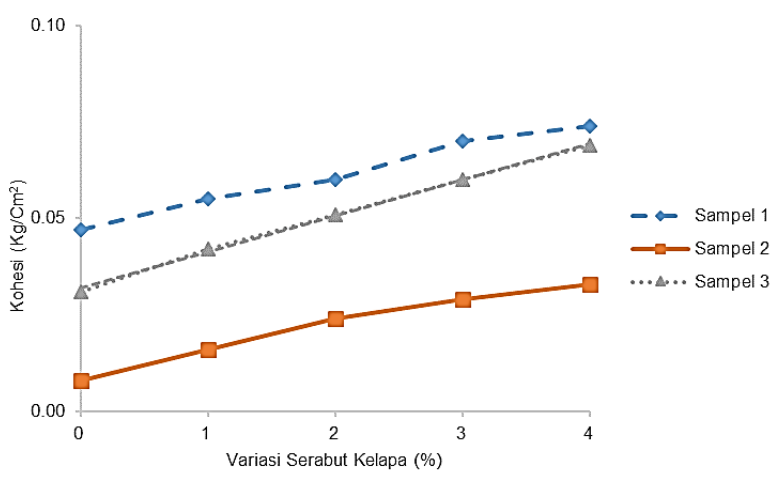

Gambar 3. Hubungan kadar serabut kelapa dengan kohesi
Pengujian geser langsung (Direct Shear Test) dengan penambahan serabut kelapa, dapat kita lihat pada tabe 2 dan gambar 3 dimana pada setiap pengujian dengan variasi penambahan serabut kelapa nilai kohesi mengalami peningkatan. Dimana dapat dilihat bahwa setiap kenaikan $1 \%$ penambahan serabut kelapa kohesinya mengalami peningkatan sekitar 0,2\%.

Tabel 3. Hasil pengujian geser langsung (sudut geser)

\begin{tabular}{cccc}
\hline $\begin{array}{c}\text { Variasi } \\
\text { serabut } \\
(\%)\end{array}$ & \multicolumn{3}{c}{ Sudut Geser $\left(^{\circ}\right)$} \\
\hline 0 & Sampel 1 & Sampel 2 & Sampel 3 \\
1 & 8 & 20 & 7 \\
2 & 8 & 21 & 7 \\
3 & 9 & 21 & 8 \\
4 & 9 & 22 & 9 \\
& 10 & 22 & 9
\end{tabular}

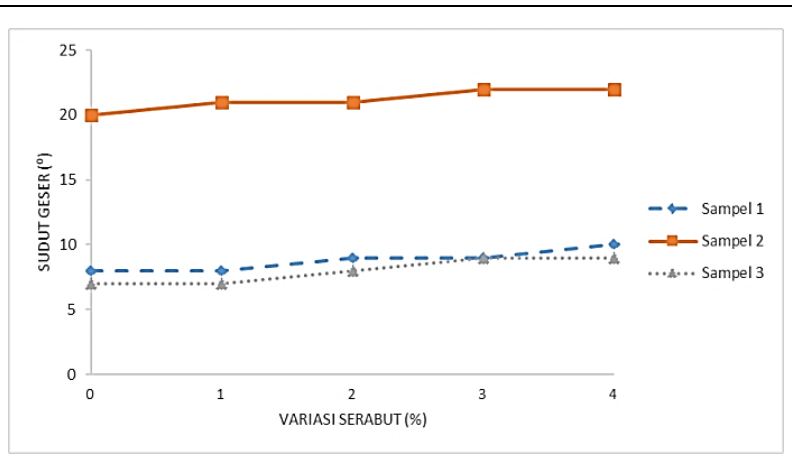

Gambar 3. Hubungan kadar serabut kelapa dengan sudut geser $(\varphi)$

Pengujian geser langsung (Direct Shear Test) dengan penambahan serabut kelapa, dapat kita lihat pada tabel 3 dan gambar 4 dimana pada setiap pengujian dengan variasi penambahan serabut kelapa nilai sudut geser mengalami peningkatan. Dimana dapat dilihat bahwa setiap kenaikan $1 \%$ penambahan serabut kelapa nilai sudut gesernya mengalami peningkatan sekitar $0,1 \%$.

\section{KESIMPULAN}

Berdasarkan hasil penelitian diperoleh kesimpulan tanah yang digunakan adalah tanah lempung organic dengan plastisitas sedang dan pengujian 
geser langsung (direct shear test) menunjukkan adanya peningkatan nilai kohesi (c) dan sudut geser $(\varphi)$ tanah. Hal ini menunjukkan bahwa penambahan serabut kelapa pada tanah lempung dapat meningkatkan nilai kuat geser.

\section{DAFTAR PUSTAKA}

[1] Hardiyatmo, C. 2002. Mekanika Tanah I. Yogyakarta: Gajah Mada University Press.

[2] Lastiko, H. S. 2017. Stabilitas Tanah Menggunakan Serabut Kelapa Melalui Uji Geser Langsung (Direct Shear Test). RENOVASI: Rekayasa dan Inovasi Teknik Sipil, Volume 2. HIm.9-16.

[3] Rahmadani. 2011. Pengaruh Penambahan Serabut Kelapa Terhadap Parameter Kuat Geser Tanah Berpasir. Jurnal Universitas Tadulako. Volume 9. Nomor 3. HIm.187-195.

[4] Sukmoyudho, N. S. (2019). Pengaruh Penambahan Serat Sabut Kelapa Segai Bahan Campuran Untuk Memperkuat Timbunan Tanah Lempung. Skripsi. ITN
Malang. (Tersedia di http://eprints.itn.ac.id/id/eprint/4394)

[5] Sulistyo, B. (2013). Pengaruh Serabut Terhadap Kuat Geser dan Tekan Bebas Tanah Berbutir Hasil.

[6] D. M. Pangandongan, R. Rachman and I. L. K. Wong, 2020, "Pengaruh Penambahan Bubuk Gypsum Pada Tanah Lempung Terhadap Uji California Bearing Ratio (CBR)," Paulus Civil Engineering Journal, vol. 2, no. 4, pp. 263-272. 